\title{
Teaching and Instructional Design Approaches to Enhance Students' Self-Directed Learning in Blended Learning Environments
}

\author{
Dina Adinda and Najoua Mohib \\ LISEC EA2310, University of Strasbourg, France \\ d.adinda@unistra.fr \\ najoua.mohib@unistra.fr \\ DOI: 10.34190/EJEL.20.18.2.005
}

\begin{abstract}
Thanks to the combination of face-to-face and online learning which involve the use of Information and Communication Technology (ICT), blended learning has become a popular approach to support learning in higher education. The main purpose of this study is to identify the teaching and instructional design approaches adopted by lecturers within blended learning environments, and to analyse their effects on students' self-directed learning. The sample involves 18 lecturers and their undergraduate students $(n=294)$ undertaking a blended course in one French university. This research utilised a mixed method approach for data collection, including questionnaires and observations. Firstly, lecturers were invited to declare their teaching approaches and the configuration of their blended learning environments by completing two online questionnaires. Secondly, both face-to-face and online observations were conducted with the lecturers to identify the specificity of their instructional design activities. A pre-post questionnaire was also used to measure students' selfdirected learning level. Data collection took place over a period of 6 months during the academic year 2017-2018. The results show that lecturers who adopt student-centred teaching approaches are not necessarily designing their blended learning courses as a student-centred learning environment. Also, the results reveal that students' self-directed learning is significantly developed only in three out of seven student-centred blended learning courses. Additionally, the results show that lecturers of the students who improved their self-directed level provided online peer review and online forum discussion activities. The findings indicate that further research is needed both to validate the direct relationship between these kinds of pedagogical activities and the self-directed learning, and to determine how blended learning environments can better support collaboration and interaction.
\end{abstract}

Keywords: Blended learning, teaching approaches, instructional design, self-directed learning, undergraduate students, online discussion forum.

\section{Introduction}

Since digital technologies are continually being created and disseminated, the demands of the labour market are also evolving continuously. Consequently, education should provide skills needed for $21^{\text {st }}$ century individuals to develop as persons, citizens, and professionals. Rimini and Sipezia (2016) reported for the OECD that selfdirection is one of the crucial skills to enable individuals to face the challenges of the digital world. The importance of self-direction has been long ago put forward by Knowles $(1975$, p. 18) who defined it as a process "in which individuals take the initiative, with or without the help of others, in diagnosing their learning needs, formulating learning goals, identifying human and material resources for learning, choosing and implementing appropriate learning strategies, and evaluating learning outcome”. For Knowles (1975), people who get into this process learn more and better than those who do not. This idea is still supported by some researchers (Bagheri, et al., 2013) who point out the necessity to help students to improve their self-directed learning skills in order to be successful, both in academic work and in life. With this comes the question: how to improve students' selfdirected learning?

The international literature suggests that blended learning could be considered as a good way to achieve this goal. Although blended learning is defined as combining online and face-to-face instructional strategies (Garrison and Kanuka, 2004; Graham, 2006), many researchers have underlined its benefits for students. Blended learning environments are supposed to enhance students' engagement (Page, et al., 2017), to increase their motivation (López-Pérez, Pérez-López and Rodríguez-Ariza, 2011), and to improve as well their selfregulated (Barnard, et al., 2009) and self-directed learning skills (Akgunduz and Akinoglu, 2016; Uz and Uzun, 2018). All these positive impacts seem to be one of the reasons for its implementation in higher education (Kintu, Zhu and Kagambe, 2017; Ibrahim, et al., 2017). It is a widely held view that the benefits of blended learning are due to the possibilities given by technology. Lam (2014), for example, argued that the use of multimedia tools in a blended learning environment promotes students' self-direction in learning. However, Van Laer and Elen 
(2016) and Ibrahim, et al. (2017) found that researches on blended learning mostly examine the impact of technology, leaving aside the pedagogical aspect.

The purpose of this study is to explore more fully this issue by analysing the effects of teaching and instructional design approaches on students' self-directed learning in a blended learning context. While a number of researchers highlight the advantages of blended learning, Poon (2003) states that the quality of learning achievement depends, to a large extent, both on the teachers' conception of teaching and learning and the type of teaching-learning environment provided. The key research question in this paper is: "what are the effective teaching and instructional design approaches that enhance students' self-directed learning within a blended learning environment?" The next section presents the literature review followed by the methodology (participants and research design) and the findings. The paper ends with a discussion and a conclusion.

\section{Literature review}

\subsection{Blended learning instructional approach}

Blended learning can be defined as an instructional teaching approach that combines online and face-to-face teaching and learning sessions (Boelens, et al., 2015). This definition is generally shared by other researchers (Horn and Staker, 2015) although various definitions depending on the context exist (Graham, 2006). For Garrison and Kanuka (2004), the effective combination of the two instructional methods is the main challenge. Some researchers (Peraya, et al., 2012; Horn and Stakers, 2015) highlight the importance of articulating online and face-to-face teaching to enable students to control their activities. While Graham $(2013$, p.23) claims that theorical frameworks are helpful to "guide practice", Lebrun, et al. (2014, pp.64-71) suggest a typology of 6 configurations of blended learning environments: "scene", "screen", "cockpit", "crew", "metro" and "ecosystem". All these configurations have been classified into two instructional design approaches: teachercentred and student-centred learning. Table 1 gives a description of each configuration.

Table 1: A typology of blended learning environment (Peraya and Peltier, 2012; Peraya, Charlier and Deschryver 2014)

\begin{tabular}{|l|l|l|}
\hline $\begin{array}{l}\text { Instructional design } \\
\text { approach }\end{array}$ & Configuration & Description \\
\hline \multirow{3}{*}{$\begin{array}{l}\text { Teacher-centred approach } \\
\text { (SCA) }\end{array}$} & 1. Scene & $\begin{array}{l}\text { Content-oriented configuration. The online environment is composed } \\
\text { principally of textual resources, which are used to support the face-to- } \\
\text { face course. }\end{array}$ \\
\cline { 2 - 3 } & 2. Screen & $\begin{array}{l}\text { Content-oriented configuration. The online environment is used to } \\
\text { support the face-to-face course. The resources provided online are } \\
\text { composed of textual and numerous multimedia resources. }\end{array}$ \\
\hline \multirow{3}{*}{$\begin{array}{l}\text { Student-centred approach } \\
\text { (SCA) }\end{array}$} & $\begin{array}{l}\text { The online management tools are used to allow students to manage } \\
\text { their learning. Several reflexive activities are also provided. }\end{array}$ \\
\cline { 2 - 3 } & 3. Cockpit & $\begin{array}{l}\text { This model focuses on building knowledge and supporting } \\
\text { interpersonal interaction. }\end{array}$ \\
\cline { 2 - 3 } & $\begin{array}{l}\text { This model fosters students' freedom of choice. It provides a } \\
\text { possibility for students to access external resources, offers mentoring, } \\
\text { and supports interaction among students. }\end{array}$ \\
\cline { 2 - 3 } & 6. Ecosystem & $\begin{array}{l}\text { This model is characterised by the exploitation of a large number of } \\
\text { technological and educational possibilities. It provides, for example, a } \\
\text { possibility for students to choose their own learning path. }\end{array}$ \\
\hline
\end{tabular}

This typology has been developed through a European project "HY SUP" (2009-2012) that aimed to both describe the blended learning environments designed in Higher Education (Belgium, France, Luxembourg, Switzerland) and to analyse the impact of blended learning practices on the learning-teaching process. Peraya, Charlier and Deschryver (2014) have identified 5 pedagogical dimensions (see Table 2) for each blended learning environment as follows : "combination" which refers to inter-mixing online and face-to-face strategies (1), "mediatisation" defined in terms of e-learning and instructional design (2), "mediation" related to the effects of media on behaviours (3), "teacher and student mentoring" including cognitive, metacognitive and motivational components (4), and "degree of openness" or "flexibility" that makes it possible for students to select the way of learning and the resources they need and to interact with the external actors (5). 
Table 2: Pedagogical dimensions and components of blended learning environments (Peraya and Peltier, 2012; Lebrun et al., 2014)

\begin{tabular}{|c|c|}
\hline Dimensions & Constitutive components \\
\hline \multirow[t]{2}{*}{ 1. Combination } & Students' participation in face-to-face sessions \\
\hline & Students' participation in the online platform \\
\hline \multirow[t]{6}{*}{ 2. Mediatisation } & Provision of learning tools \\
\hline & Provision of management, communication, and interaction tools \\
\hline & Resources in multimedia format \\
\hline & Works in multimedia form \\
\hline & Synchronous communication and collaboration tools used \\
\hline & Possibility provided to students to comment and annotate documents \\
\hline 3. Mediation & Reflexive and relational objectives \\
\hline \multirow{3}{*}{$\begin{array}{l}\text { 4. Teacher and student } \\
\text { mentoring }\end{array}$} & Methodological supports provided by the teacher \\
\hline & Metacognitive supports provided by the teacher \\
\hline & Peer-support \\
\hline \multirow{2}{*}{$\begin{array}{l}\text { 5. Degree of openness or } \\
\text { flexibility }\end{array}$} & Freedom of choice of learning methods \\
\hline & Use of resources and external actors \\
\hline
\end{tabular}

The six "HY SUP" typology is very popular in the French-speaking research area and gave rise to several publications (see project website HY-SUP) revealing that student-centred approaches have positive effects on students' engagement and motivation in the blended learning context. However, Peraya, Charlier and Deschryver (2014) recognize that further researches need to be conducted to know more about the impacts of the 6 configurations of blended learning environments on the learning process. For example, no evidence has been given yet to declare with Jézégou (2014) that student-centred blended learning approach ("crew", "metro", "ecosystem" configurations) encourage students to take control of their own learning. If this typology is very interesting to keep, it is focused only on the instructional design approach. Therefore, it is also important to take into account the teaching approaches regarding their potential effects on students' learning outcomes (Gerbic, 2011).

\subsection{Teaching approaches}

For Kember (1997) and many others (Trigwell, Prosser and Taylor, 1994; Trigwell, Prosser and Waterhouse, 1999; Prosser, et al., 2005), teaching approaches are related to conceptions of teaching, which are influenced by their beliefs about teaching and their perception of their teaching environment. These approaches can be distinguished in two ways: "teacher-centred/content" and "student-centred/learning" (Kember, 1997). All these categories are summarised below in the Table 3.

Trigwell, Prosser and Waterhouse (1999) established a relationship between teachers' approaches to teaching and students' approaches to learning. For these authors, teacher-centred approach is related to a surface approach, whereas student-centred approach is associated with a deep approach to learning. Similarly, Kember, Leung and Mcnaught (2008) observe that teachers' approaches focused on transmitting knowledge and information are more likely to promote surface learning approaches, whereas teachers' approaches focused on supporting a greater level of students' interaction and discussion tend to promote deep learning approaches. On the one hand, when the teachers focus on their teaching, they pay more attention to knowledge transfer and students' notes. On the other hand, when they focus on students, they provide opportunities for active learning in which students are actively involved in their learning, not only to listen and receive knowledge transferred, but also to engage in "higher-order thinking tasks" like discussion, solving problems, analysis, synthesis, evaluation (Bonwell and Eison, 1991, p.5), and to think about their own actions or activities (Prince, 2004). According to Kane (2004), active learning also supports critical thinking, fosters autonomy, and ensures that students become the actor of their learning. In fact, many studies establish a close link between studentcentred teaching approaches and self-directed learning (Plush and Kehrwald, 2014; Horn and Staker, 2015). 
Table 3: A model of teachers' approaches (adapted from Kember, 1997; Kember and Kwan, 2000)

\begin{tabular}{|l|l|l|}
\hline Teachers' approaches & Conceptions of teaching & Teaching activities \\
\hline $\begin{array}{l}\text { Content-centred or Teacher- } \\
\text { centred approach (TCA) }\end{array}$ & Imparting information & $\begin{array}{l}\text { Teachers' objective is to transfer all the information that } \\
\text { students need. Examples of activity: lecture-based } \\
\text { teaching or "chalk and talk." }\end{array}$ \\
\hline $\begin{array}{l}\text { Content-centred or Teacher- } \\
\text { centred approach (TCA) }\end{array}$ & $\begin{array}{l}\text { Transmitting structured } \\
\text { knowledge }\end{array}$ & $\begin{array}{l}\text { Teachers' objective is to transfer the information and to } \\
\text { help students to understand it (students are informed of } \\
\text { the lesson plan; teachers use examples and analogies). } \\
\text { Examples of activity: lecture-based teaching with a } \\
\text { structured guide. }\end{array}$ \\
\hline-3 Learning-centred or & Facilitating understanding & $\begin{array}{l}\text { Teachers' objective is to help students to learn by } \\
\text { themselves and to "become more effective as a teacher." } \\
\text { Examples of activity: debate, tutorial, project-based } \\
\text { learning, working in small groups. }\end{array}$ \\
$\begin{array}{l}\text { Student-centred approach } \\
\text { (SCA) }\end{array}$ & $\begin{array}{l}\text { Conceptual } \\
\text { change/intellectual } \\
\text { development }\end{array}$ & $\begin{array}{l}\text { Teachers' objective is to promote the evolution of } \\
\text { students' understanding and perspective of the subject } \\
\text { matter. Their aim is to become "more effective in } \\
\text { facilitating students' learning." Examples of activity: } \\
\text { debate, reflexive discussions, problem-based learning. }\end{array}$ \\
\cline { 2 - 3 } & & \\
\hline
\end{tabular}

\subsection{Self-directed learning}

The term of "self-directed learning" is grounded in two concepts: self-determination and self-regulation (Carré, 2003). In this perspective, learning involves motivation, control, and goal setting. The self-determination (hereafter SDT) is a core concept widely used in educational research to explain learner motivation defined as a process in which an individual seeks to satisfy one of his/her three fundamental human innate needs: competence, relatedness, and autonomy (Deci and Ryan, 2000a). Self-directed learning (hereafter SDL) and selfregulated learning (hereafter SRL) are usually used as synonyms (Loyens, Magda and Rikers, 2008; Saks and Leijen, 2014). Cosnefroy and Carré (2014, pp.2-3) argue that both concepts are "close neighbours" and may be complementary in terms of their characteristics (learners, approaches, and scope). Although similarities are more emphasised than differences (Loyens, Magda and Rikers, 2008), there are some specific definitions due mainly to the various theoretical frameworks (Noël and Cartier, 2016). From the social cognitive perspective, self-regulation "refers to self-generated thoughts, feelings, and actions that are planned and cyclically adapted to the attainment of personal goals" (Zimmerman, 2005, p. 14). As a result, self-regulated students use processes such as goal setting, self-evaluation and learning strategies, that can be taught (Zimmerman, 2002). Similarly, Cosnefroy and Carré (2014) explain that SDL can be described as a process in which learners are able to diagnose their learning needs, formulate their learning goals, identify their resources for learning, choose and implement their learning strategies, and evaluate learning outcomes. As stated by Loyens, Magda and Rikers (2008), followed by Cosnefroy and Carré (2014), SDL both requires SRL and implies more student control, especially at the beginning of the learning process. To sum up, to become a self-directed learner, students need to practice self-regulation as well as self-determination (Deci and Ryan, 2000b).

The SDL concept has attracted widespread interest both in the research domain and as professional practices (teachers, adult educators, policy-makers, ...) over the past few years. SDL is currently considered as playing a crucial role in learning processes especially in deep-level processing (Candy, 1991). The existing researches on SDL have demonstrated correlations with performance outcomes and academic achievement, especially in online environments (Dabbagh, 2007; Lounsbury, et al., 2009; López-Pérez, Pérez-López and Rodríguez-Ariza, 2011). It is argued that open and distance environments are designed to foster self-direction by giving a student the freedom to choose how and what to learn as well as encouraging social interactions between learners (Carré, et al., 2011). Recent research suggests also that blended learning environments help students to develop their self-directed learning skills (Sriarunrasme, Techataweewan and Mebusaya, 2015; Uz and Uzun, 2018). However, there are few studies of lecturers' approaches to teaching in blended learning context and their relationship with approaches of instructional design.

\subsection{Research objectives and hypothesis}

A number of authors (Loyens, Magda and Rikers, 2008; Van den Akker, et al., 2013) point out that the teachers' role is to support students to become self-directed learners. As mentioned earlier, two approaches, "the teacher-centred" and "the student-centred" ones, can be identified both for teaching (Trigwell, Prosser and 
Taylor, 1994) and blended learning instructional design (Peraya and Peltier, 2012). This study seeks to examine which teaching and instructional design approaches may help students to increase their self-directed learning skills in a blended learning context. Hence, it could conceivably be hypothesised that: firstly, lecturers who adopt student-centred teaching approaches are more likely to design their blended learning courses as a studentcentred learning environment; and secondly, student-centred teaching approaches associated with blended student-centred approaches enhance students' self-directed learning.

\section{Methodology}

\subsection{Participants}

The sample consisted of 18 lecturers and 294 undergraduate students enrolled in a blended learning course offered by a French university during the 2017-2018 academic year. A total of eight academic disciplines were represented: sociology, foreign languages, mathematics, economics, law, physics, educational sciences, and communication. All participants (lecturers and students) were briefed on the main aim of the study and signed informed consent forms in accordance with the guidelines of the university's Research Ethics Committee. The participants were assured that their response would remain confidential and anonymous. They were also free to withdraw from the study at any stage.

\subsection{Research methods}

This study used a mixed methods design that combines both quantitative and qualitative approaches. The goal of the mixed methods approach was to gain a deep understanding of the impact of the pedagogical approaches used in blended learning on students' self-directed learning. Qualitative and quantitative data were collected, through questionnaires, to identify the lecturers' teaching and instructional design approaches that impact positively the students' self-directed learning in a blended learning context. Both offline and online classroom observations were also conducted in order to examine the instructional activities offered in the student-centred blended learning environments. The data collection and procedures are described in more details in the following section.

\subsection{Data collection}

\subsubsection{Data Collection from Lecturers}

Different instruments (questionnaires and observations) have been used with all the lecturers $(n=18)$. Lecturers were asked, just before their first course, to fill out an online questionnaire: The Approach to Teaching Inventory (ATI) (Trigwell, Prosser and Ginns, 2005). This questionnaire (ATI) seemed to be relevant for this study case because it was developed in order "to explore the relations between a teacher's approaches to teaching and the approaches to learning of students in the classes of those teachers" (Trigwell and Prosser, 2004, p.416). Another reason which explains the choice of this instrument is that Prosser and Trigwell (2006) consider that teachers' approaches to teaching are contextual and it can differ from one context to another. In other words, teachers may adopt different approaches in different circumstances (Prosser, et al., 2005). Consequently, it is essential to identify teachers' approaches in a specific course to understand the intentions and strategies they adopt for their teaching. The original 22-item ATI consisted of 11 items on "conceptual change/student-centred teaching approaches" scale and 11 items on "information-transmission/teacher-centred teaching approach" scale. Each of them, constructed by two subscales ("teaching intention" and "strategy"), was rated on a 5-point Likert scale (from 1: only rarely to 5: almost always). Although ATI is a popular instrument, only a Canadian French translation has been found for the original 16-item ATI (Trigwell and Prosser, 2004). For this work, the original 22-item ATI was translated into French by native speakers with expertise in education. The overall reliability generated for this French version of ATI was 0.815 Cronbach's alpha. However, the Pearson test conducted to determine the validity of the instrument showed that the correlation of each item to their respective scales was generally strong except for item $2(r=0,180)$. The removal of this item didn't affect the validity of the instrument and the overall Cronbach's alpha of the 21-item ATI remained good $(\alpha=0,747)$.

Immediately after the first questionnaire was collected, the lecturers completed a second online questionnaire: the Self-Positioning Tool (SPT) (Deschryver and Charlier, 2012). The SPT has been developed in the HY-SUP European research project to identify configurations of the blended-learning environment, which can be used to analyse the effects on students' learning and teachers' professional development. Each lecturer was invited to examine his blended-learning course using the SPT. This questionnaire consisted of 12 closed questions. 6 questions referred to personal data (age, sex, experience, ...), the courses (number of students, level of study, 
face to face time) and the learning platform. The 6 other questions aimed to measure the 14 blended learning components described above in the literature review, in order to determine which configuration of blended learning teachers have implemented. These 6 questions were evaluated on a 4-point scale (frequency or attitude). The SPT is only available in French. The validity of the instrument has already been demonstrated by Deschryver and Charlier (2012).

Both online and face-to-face observations were also conducted with the 18 lecturers by the authors over a period of one semester. On the one hand, each face-to-face class was observed twice for 50 minutes. The first observation was scheduled during the pre-test with the students (see section 3.3.2) whereas the second one took place one week before the post-test. An observation instrument was developed especially for this study and showed a good internal consistency $(\alpha=0,747)$. The instrument comprised four dimensions (directive mentoring style, supporting mentoring style, proactive/reactive interventions, context) and 15 items.

On the second hand, online observations were carried out near the middle of the semester. All the courses were hosted on Moodle. The following aspects were examined in depth: the tools (wiki, forum, chat, ...), the resources (videos, power point slides, articles, ...) and the pedagogical activities (discussion, debate, peer assessment, ...) including the instructions of the lecturers, that were provided for the students to learn. The information collected through both face-to-face and online observations aimed to discern the aspects that can support students' self-directed learning in a student-centred blended learning environment.

\subsubsection{Data Collection from Students}

To examine the effects of the teaching and instructional design approaches on students' SDL in a blended learning environment, a pre- and post-test were conducted using the Self-Directed Learning Readiness Scale (SDLRS) (Guglielmino, 1977). The SDLRS has been designed to measure the degree to which individuals perceive their skills and attitudes necessary for self-directed learning along 8 factors: "self-concept as an effective learner", "openness to learning opportunities", "initiative and independence to learning", "acceptance of responsibility for one's own learning", "love of learning", "creativity", "Ability to use basic study and problem-solving skills" and "positive orientation to the future" (Field, 1989). The instrument is a 58-item questionnaire with a 5-point scale Likert type response options, ranging from "almost never true" to "almost always true". The questionnaire has been validated in various contexts and translated into many languages. In the current study, the French-translated version was used. The study was carried out over a semester period and a paper questionnaire was given twice to the students, once during the first face-to-face course (i.e. pretest) and again before the last one (i.e. post-test). The Cronbach's alpha coefficient obtained for the overall items of the scale is 0.843 , indicating good internal consistency of reliability.

\section{Findings}

The data gathered from the lecturers through both the questionnaires (ATI and SPT) and the observations (faceto-face and online courses) have been analysed qualitatively whereas the students' responses were examined by a paired sample t-test.

\subsection{Teaching and blended learning instructional approaches}

Lecturers' responses $(n=18)$ to ATI and SPT questionnaires have been gathered in one table; Table 4 shows that lecturers' approaches to teaching and to design blended learning may be divergent or convergent. By taking into account the teachers' teaching approaches and the blended learning instructional approaches, 4 combinations emerged: the student-centred (7 lecturers; $B, C, D, F, K, L, P$ ), the teacher-centred (4 lecturers; $E, G, H, J$ ), the student/teacher-centred (4 lecturers; A, I, M, N) and the teacher/student-centred (3 lecturers; O, Q, R). These results demonstrate that lecturers who adopt a student-centred teaching approach are not necessarily designing their blended learning courses as a student-centred learning environment. Among the 11 lecturers who use a student-centred teaching approach, 4 of them adopt a teacher-centred blended learning approach while 7 of them adopt a student-centred blended learning approach. Accordingly, the first hypothesis is not fully confirmed. 
Table 4: Results from the Approach to Teaching Inventory (ATI) (Trigwell, Prosser and Ginns, 2005) and the Self-Positioning Tool (SPT) (Deschryver and Charlier, 2012)

\begin{tabular}{|l|l|l|l|}
\hline Lecturers ID & $\begin{array}{l}\text { Teachers' } \\
\text { teaching approach }\end{array}$ & $\begin{array}{l}\text { Blended learning } \\
\text { configuration }\end{array}$ & $\begin{array}{l}\text { Blended learning instructional } \\
\text { approach }\end{array}$ \\
\hline A & Student-centred & Scene & Teacher-centred \\
\hline B & Student-centred & Metro & Student-centred \\
\hline C & Student-centred & Metro & Student-centred \\
\hline D & Student-centred & Metro & Student-centred \\
\hline E & Teacher-centred & Scene & Teacher-centred \\
\hline F & Student-centred & Metro & Student-centred \\
\hline G & Teacher-centred & Screen & Teacher-centred \\
\hline H & Teacher-centred & Scene & Teacher-centred \\
\hline I & Student-centred & Screen & Teacher-centred \\
\hline J & Teacher-centred & Screen & Teacher-centred \\
\hline K & Student-centred & Metro & Student-centred \\
\hline L & Student-centred & Metro & Student-centred \\
\hline M & Student-centred & Cockpit & Teacher-centred \\
\hline N & Student-centred & Cockpit & Teacher-centred \\
\hline O & Teacher-centred & Crew & Student-centred \\
\hline P & Student-centred & Metro & Student-centred \\
\hline Q & Teacher-centred & Seacher-centred & \\
\hline R & Teadent-centred \\
\hline
\end{tabular}

In addition, the 6 configurations of blended learning environments, as described above by Peraya, et al. (2012) have been mentioned by the lecturers. Table 5 below indicates that the most represented configuration is "Metro", which referred to a student-centred blended learning instructional approach. As well as to support students' active participation in online and face-to-face session, Deschryver and Charlier (2012) state that this configuration of blended learning environment aims to provide students' freedom of choice by giving them the possibility to access external resources, offering human mentoring and supporting active interactions through peer reviews, peer-mentoring or mentoring from tutor/lecturer. The supports provided can be managed in the online platform or in face-to-face sessions through various actions (online forum discussion, wiki, group project, online or offline individual peer review, etc.).

Table 5: Frequencies of blended learning instructional approaches from the lecturers' responses to the SelfPositioning Tool (SPT) (Deschryver and Charlier, 2012)

\begin{tabular}{|c|c|c|c|c|}
\hline $\begin{array}{l}\text { Blended learning instructional } \\
\text { approach }\end{array}$ & $\begin{array}{l}\text { Blended } \\
\text { learning } \\
\text { configuration }\end{array}$ & $\begin{array}{l}\text { Frequency } \\
(\mathrm{N}=18)\end{array}$ & Percentage per type & $\begin{array}{l}\text { Percentage per } \\
\text { approach }\end{array}$ \\
\hline \multirow{3}{*}{$\begin{array}{l}\text { Teaching-centred } \\
(A, E, G, H, I, J, M, N)\end{array}$} & Scene & 3 & $17 \%$ & \multirow{3}{*}{$46 \%$} \\
\hline & Screen & 3 & $17 \%$ & \\
\hline & Cockpit & 2 & $12 \%$ & \\
\hline \multirow{4}{*}{$\begin{array}{l}\text { Student-centred } \\
(B, C, D, F, K, L, O, P, Q, R)\end{array}$} & Crew & 1 & $5 \%$ & \multirow{3}{*}{$54 \%$} \\
\hline & Metro & 8 & $44 \%$ & \\
\hline & Ecosystem & 1 & $5 \%$ & \\
\hline & & $N=18$ & $100 \%$ & \\
\hline
\end{tabular}

In order to examine the second hypothesis that student-centred teaching and blended learning instructional approaches would enhance students' self-directed learning, the following analysis is focused only on the student-centred approach, i.e. lecturers who declare that they adopt both student-centred approach to teaching and to design their blended learning course. Table 6 describes the specific instructional activities adopted by the 7 student-centred lecturers that have been observed by the authors of the present paper. All the blended learning courses refer to the "Metro" configuration, which is defined by Deschryver and Charlier (2012, p.59) as 
a "learning configuration focused on various forms of support and tending toward openness". According to these authors, the specificity of the "Metro" blended learning configuration is the possibility to access external resources and human mentoring provided by lecturers and to receive peer supports. According to the description presented below, all courses identified as "Metro" allow students to choose and to access external resources.

Table 6: Results from the face-to face and online observations of student-centred lecturers $(n=7)$

\begin{tabular}{|c|c|c|c|}
\hline $\begin{array}{l}\text { Lecturers } \\
\text { ID }\end{array}$ & $\begin{array}{l}\text { Teachers' } \\
\text { Teaching } \\
\text { approaches }\end{array}$ & $\begin{array}{l}\text { Blended Learning } \\
\text { configuration and } \\
\text { Instructional approach }\end{array}$ & $\begin{array}{l}\text { Specific instructional activities (online and face-to-face } \\
\text { observations) }\end{array}$ \\
\hline$B$ & Student-centred & Metro (SC) & $\begin{array}{l}\text { Students are free to choose and to access external } \\
\text { resources to enrich their knowledge and to complete the } \\
\text { exercises on Moodle. The knowledge transfer in face-to- } \\
\text { face sessions are mostly managed through discussions } \\
\text { and project presentations. Teaching is based on both } \\
\text { individual and group project-based learning. }\end{array}$ \\
\hline C & Student-centred & Metro (SC) & $\begin{array}{l}\text { Students are encouraged to access external resources to } \\
\text { enrich their knowledge and to complete the exercises on } \\
\text { Moodle. Most of the course contents are delivered online. } \\
\text { The face-to-face sessions are intended for a question and } \\
\text { answer section or discussions to support students' critical } \\
\text { thinking, reflexivity and their understanding of the subject } \\
\text { learned. However, in some conditions (such as students' } \\
\text { passive participation in the discussion), the lecturer also } \\
\text { transfers the knowledge in a traditional lecture format. }\end{array}$ \\
\hline$D$ & Student-centred & Metro (SC) & $\begin{array}{l}\text { Students can participate in an event organised by external } \\
\text { persons (optional activity). An online news and } \\
\text { announcement is used to provide information about the } \\
\text { learning activities (task deadlines, academic calendar, ...). } \\
\text { Small groups discussions and peer review activities are } \\
\text { organised during face-to-face sessions. }\end{array}$ \\
\hline $\mathrm{F}$ & Student-centred & Metro (SC) & $\begin{array}{l}\text { Students are free to choose and to access external } \\
\text { resources. An online discussion forum is available for } \\
\text { communication. The students are encouraged to ask } \\
\text { questions and to read the answers posted by the lecturer } \\
\text { before face-to-face sessions. The face-to-face sessions } \\
\text { are intended for a question and answer section or } \\
\text { discussions to support students' critical thinking, reflexivity } \\
\text { and their understanding of the subject learned. }\end{array}$ \\
\hline K & Student-centred & Metro (SC) & $\begin{array}{l}\text { Students are free to choose and to access external } \\
\text { resources. Teaching is based on project-based learning. } \\
\text { To accomplish the task given, students are encouraged to } \\
\text { ask questions via an online discussion forum in which the } \\
\text { lecturer provides instructions and detailed information. The } \\
\text { face-to-face sessions are intended for discussions to } \\
\text { support the progress of the project, students' critical } \\
\text { thinking, and their reflexivity. Peer review activities are } \\
\text { organised regularly, in face-to-face and online platforms, to } \\
\text { assess the quality of the project submitted. }\end{array}$ \\
\hline $\mathrm{L}$ & Student-centred & Metro (SC) & $\begin{array}{l}\text { Students are free to choose and to access external } \\
\text { resources provided by the lecturer on Moodle. Teaching is } \\
\text { also based on both individual and group project-based } \\
\text { learning. The transfer of knowledge in face-to-face } \\
\text { sessions is managed through the exercises, the question } \\
\text { and answer section, and presentations. Peer review } \\
\text { activities are organised during face-to-face sessions. }\end{array}$ \\
\hline$P$ & Student-centred & Metro (SC) & $\begin{array}{l}\text { Students are free to choose and to access external } \\
\text { resources. An online discussion forum is available for } \\
\text { communication with the lecturer and fellow students. It is } \\
\text { used to discuss and debate students' understanding of the } \\
\text { subject matter. Peer review activities take place in the } \\
\text { online discussion forum and during face-to-face sessions. }\end{array}$ \\
\hline
\end{tabular}

Table 7 indicates that seven categories of instructional activities can be distinguished: (1) face-to-face discussions to encourage students' reflexivity, critical thinking and understanding (2) face-to-face peer review to enhance collaboration and interactions between students, (3) face-to-face presentations to assess the value of students' knowledge, (4) online discussion forum to support both interaction and tasks achievement or to 
provide information, (5) online peer-review to enhance collaboration and interaction, (6) online news and announcement to provide additional information and (7) project-based-learning for problem solving and collaboration .

Table 7: Common and divergent specific instructional activities of student-centred lecturers $(n=7)$

\begin{tabular}{|c|c|c|c|c|c|c|c|}
\hline $\begin{array}{l}\text { Specific } \\
\text { instructional } \\
\text { activities }\end{array}$ & Lecturer B & Lecturer C & Lecturer D & Lecturer F & Lecturer $\mathrm{K}$ & Lecturer L & Lecturer $\mathbf{P}$ \\
\hline $\begin{array}{l}\text { Face-to face } \\
\text { discussions }\end{array}$ & $x$ & $x$ & $x$ & $x$ & $x$ & & \\
\hline $\begin{array}{l}\text { Face-to-face } \\
\text { peer review }\end{array}$ & & & $x$ & & $x$ & $x$ & $x$ \\
\hline $\begin{array}{l}\text { Face to face } \\
\text { presentations }\end{array}$ & $x$ & & & & & $x$ & \\
\hline $\begin{array}{l}\text { Online } \\
\text { discussion forum }\end{array}$ & & & & $x$ & $x$ & & $x$ \\
\hline $\begin{array}{l}\text { Online } \\
\text { peer review }\end{array}$ & & & & & $x$ & & $x$ \\
\hline $\begin{array}{l}\text { Online news and } \\
\text { announcement }\end{array}$ & & & $x$ & & & & \\
\hline $\begin{array}{l}\text { Project based } \\
\text { learning }\end{array}$ & $x$ & & & & $x$ & $x$ & \\
\hline
\end{tabular}

\subsection{Students' self-directed learning in student-centred blended learning courses}

The following analysis deals only with the students $(n=152)$ who were enrolled in the courses taught by the 7 student-centred lecturers ( $B, C, D, F, K, L, P)$. All of students responded to both pre and post-test questionnaires. A paired sample t-test was performed to determine the significance of the difference between pre and post-test in order to identify students' progress regarding their level of SDL skills.

Table 8: Paired samples T-test results of Students' Self-Directed Learning Readiness Scale (Guglielmino, 1977)

\begin{tabular}{|l|l|l|l|l|l|}
\hline Lecturers ID & Pre-test & Post-test & p-value & Students' t-test results & Number of students \\
\hline B & 216.8 & 216.4 & 0.530 & $\mathrm{~ns}$ & 16 \\
\hline C & 210.9 & 210.6 & 0.565 & $\mathrm{~ns}$ & 62 \\
\hline D & 226.1 & 226.1 & 0.500 & $\mathrm{~ns}$ & 8 \\
\hline F & 214.0 & 218.1 & 0.075 & $\mathrm{t}=1.505 ; \mathrm{p}<.10, \mathrm{df} 18$ & 19 \\
\hline K & 208.7 & 215.9 & 0.011 & $\mathrm{t}=2.577 ; \mathrm{p}<.05, \mathrm{df} 13$ & 14 \\
\hline L & 198.4 & 201.1 & 0.209 & $\mathrm{~ns}$ & 18 \\
\hline P & 201.5 & 232.6 & $<.001$ & $\mathrm{t}=-7.684 ; \mathrm{p}<.001, \mathrm{df} 14$ & 15 \\
\hline
\end{tabular}

Referring to the average pre-test results of each lecturer, it is shown that the majority of students scored 'average' and 'below' on the SDLRS. As noted in Table 8, all student groups had not made progress in SDL. The collected data shows that 3 out of 7 student groups had made significant improvement: namely students of lecturers $F(p$-value $=0.075<0.10), K(p$-value $=0.011<0.05)$ and $P(p$-value $<0.001)$. Consequently, the second hypothesis of this study is partially supported.

According to the face-to-face and online observations that allow identification of the specific instructional activities in the blended courses (see Table 7 ), it appears that lecturers who use peer review activities (D, L) and discussions (B, C, D) only in face-to-face settings do not contribute to enhancing their students' self-directed learning level. On the contrast, students of the lecturers who have offered the same activities online (peer review for $\mathrm{K}, \mathrm{P}$; discussion for $\mathrm{F}, \mathrm{K}, \mathrm{P}$ ) showed progress in their self-directed learning. In addition, it is interesting to note that lecturers of the students who improved this ability used an online peer review $(K, P)$ and an online discussion forum (F, K, P). For lecturer F, for example, students were invited to ask questions about the lecture content and to read the answers posted by the lecturer on the forum before discussing the subject matter in face-to-face meetings. On the other hand, lecturer $\mathrm{K}$ used the forum as a communication tool for him and his students for project-based learning. During face-to-face sessions, he regularly arranged peer-review activities to check students' progress regarding their project. Lecturers K and P managed also peer-review activities. However, this activity did not only take place during face-to-face meetings but also along with online learning sessions. Furthermore, for lecturer $\mathrm{P}$, the online discussion forum was also used to debate and discuss topics as well as furthering students' understanding of concepts learned. In brief, among the three lecturers who used the discussion forum for their course, it appeared that this communication tool was used in various ways: from a simple online communication tool between students and their lecturer to an online debating place for students. 
It can thus be suggested that the online peer review and the online discussion forum in a blended learning environment may help to enhance students' self-directed learning level. This is discussed in the next section.

\section{Discussion and conclusion}

This study aimed to examine the teaching and the instructional design approaches that enhance students' selfdirected learning within a blended learning environment. Returning to the first hypothesis posed at the beginning of this study, it is possible to state that lecturers who adopt student-centred teaching approaches do not always design student-centred blended learning. It was also shown that teaching approaches and blended learning instructional approaches do not converge all the time. These results match those observed by De Kock, Sleegers and Voeten (2004) and Smit, de Brabander and Martens (2014) who argue that learning environments are seldom entirely teacher-centred or student-centred, but take on hybrid forms. As a result, the first hypothesis of this study is not fully confirmed. Regarding the second hypothesis, the data obtained through faceto-face and online observations show that student-centred blended learning environments focus on building knowledge, supporting interpersonal interactions, providing the possibility of accessing external resources, and offering technical and human supports. Whereas social interaction between learners is supposed to support self-directed learning in an online learning environment (Carré, et al., 2011), this study has found that students have significantly developed this ability only in three out of seven student-centred blended learning courses. Consequently, the second hypothesis is partially supported.

This research has also shown that supporting students' critical thinking, reflexivity and their understanding of the subject learned is not enough to help them to become self-directed learners. Indeed, it seems to be important to manage online interaction to enhance students' self-directed learning in a blended learning environment. The online peer review and the online discussion forum seem to provide potential for student learning. This also accords with previous studies (Trautmann et al., 2003; Baran and Correia, 2009) which pointed out that online peer review activities enable students to take responsibility for their own learning. The benefits of the use of an online discussion forum has also been underlined by Amandu, Muliira and Fronda (2013). Their work has shown that the online discussion forum supports peer-review and feedback, which help students to diagnose their learning needs and determine their learning plan. According to Biasutti (2017), discussion forums support learning by enabling students to interact and confront their ideas and by activating processes of inferencing, evaluating and organizing. All these results may indicate that the potential positive effect of the online peer review and the online discussion forum on the development of students' self-directed learning can be explained by the interactions provided through the reflexive activities as well as the formative feedback. By using the online peer-review or the discussion forum, lecturers offer collaborative learning through multiple channels available on the online platform. In this present study, the discussion forum was using a simple online communication tool between students and their lecturer as a place for debate for students. As a matter of fact, the peer review activities and the discussion forum have been integrated into a learning scenario, not only to increase students' active participation online, but also to enhance active learning in face-to-face sessions. However, further work is required to establish this.

Finally, a number of important limitations need to be considered. First, the size of the sample is not large enough to get generalisable results for broader blended learning contexts. Second, students should have been interviewed in order to understand how they use the tools and the resources provided by lecturers in their learning environment. To conclude, further research needs to examine more closely the relationships between student's self-directed learning and the online peer review and discussion forum activities. In the meantime, this work highlights the importance of pedagogical design and convinced us that online and face-to-face interaction and collaboration between students should be strongly articulated when it comes to designing a blended learning environment.

\section{Acknowledgments}

This research is financed by the Indonesian Endowment Fund for Education (LPDP) and supported by Lisec EA2310, University of Strasbourg.

\section{References}

Akgunduz, D. and Akinoglu, O., 2016. The Effect of Blended Learning and Social Media-Supported Learning on the Students' Attitude and Self-Directed Learning Skills in Sciences Education. The Turkish Online Journal of Educational Technology, [e-journal] 15(2), pp.106-115. Available at: <https://files.eric.ed.gov/fulltext/EJ1096457.pdf> [Accessed 21 February 2020]. 
Amandu, G.M., Muliira, J.K. and Fronda, D.C., 2013. Using Moodle E-learning Platform to Foster Student Self-directed Learning: Experiences with Utilization of the Software in Undergraduate Nursing Courses in a Middle Eastern University. Procedia - Social and Behavioral Sciences, [e-journal] 93, pp.667-683. https://doi.org/10.1016/j.sbspro.2013.09.260.

Bagheri, M., Ali, W.Z.W., Abdullah, M.C.B. and Daud, S.M., 2013. Effects of Project-based Learning Strategy on Self-directed Learning Skills of Educational Technology Students. Contemporary education technology, 4 (1), pp.15-29.

Baran, E. and Correia, A., 2009. Student-led facilitation strategies in online discussions. Distance Education, [e-journal] 30(3), pp.339-361. https://doi.org/10.1080/01587910903236510

Barnard, L., Lan, W.Y., To, Y.M., Paton, V.O. and Lai, S.-L., 2009. Measuring self-regulation in online and blended learning environments. The Internet and Higher Education, [e-journal] 12(1), pp.1-6. https://doi.org/10.1016/j.iheduc.2008.10.005.

Biasutti, M., 2017. A comparative analysis of forums and wikis as tools for online collaborative learning. Computers \& Education, [e-journal] 111, pp.158-171. https://doi.org/10.1016/j.compedu.2017.04.006.

Boelens, R., Van Laer, S., De Wever, B. and Elen, J., 2015. Blended learning in adult education: towards a definition of blended learning. Adults learners online. Available through: Gent University Library website <https://biblio.ugent.be/publication/6905076 > [Accessed 21 February 2020].

Bonwell, C.C. and Eison, J.A., 1991. Active learning: Creating excitement in the Classroom. Washington, D.C: School of Education, George Washington Univ.

Candy, P.C., 1991. Self-Direction for Lifelong Learning. A Comprehensive Guide to Theory and Practice. San Francisco, CA, USA: Jossey-Bass.

Carré, P., 2003. La double dimension de l'apprentissage autodirigé Contribution à une théorie du sujet social apprenant. Canadian Journal for the Study of Adult Education, 17(1), pp. 66-91.

Carré, P., Jézégou, A., Kaplan, J., Cyrot, P. and Denoyel, N., 2011. L'Autoformation: The State of Research On Self-(Directed) Learning in France. International Journal of Self-Directed Learning ${ }^{\circledR}$, [online] Available at: < http://kaplanconsultants.org/sites/default/files/Carre_et_al_2011.pdf > [Accessed 21 February 2020].

Cosnefroy, L. and Carré, P., 2014. Self-regulated and Self-directed Learning: Why Don't Some Neighbors Communicate? International Journal of Self-Directed Learning, International Society of Self-Directed learning, [e-journal] 11(2), pp.112. Available through: Paris Nanterre University Library website < https://hal-univ-paris10.archives-ouvertes.fr/hal01410802/ > [Accessed 21 February 2020].

Dabbagh, N., 2007. The Online Learner: Characteristics and Pedagogical Implications. Contemporary issues in Technology and Teacher Education, [online] Available at : < https://www.citejournal.org/volume-7/issue-3-07/general/theonline-learner-characteristics-and-pedagogical-implications/> [Accessed 21 February 2020].

De Kock, A., Sleegers, P. and Voeten, M. J. M. (2004). New Learning and the Classification of Learning Environments in Secondary Education. Review of Educational Research, [e-journal] 74(2), pp.141-170. https://doi.org/10.3102/00346543074002141

Deci, E.L. and Ryan, R.M., 2000a. The "What" and "Why" of Goal Pursuits: Human Needs and the Self-Determination of Behavior. Psychological Inquiry, [e-journal] 11, pp. 227-268.

Deci, E.L. and Ryan, R.M., 2000b. What is the self in self-directed learning? Findings from recent motivational research. In: G.A. Straka. ed. 2000. Conceptions of Self-Directed Learning: Theoretical and Conceptual Considerations. Münster: Waxmann. pp. 49-57.

Deschryver, N. and Charlier, B., 2012. Dispositifs hybrides, nouvelle perspective pour une pédagogie renouvelée de l'enseignement supérieur. [pdf] Lyon: HY-SUP. Available at: < http://spiralconnect.univ-lyon1.fr/spiralfiles/download? mode=inline\&data $=1757974>$ [Accessed 21 February 2020].

Field, L., 1989. Investigation into the structure, validity and reliability of Guglielmino's SDLRS. Adult Education Quarterly, [ejournal] 39, pp. 125-139.

Garrison, D.R. and Kanuka, H., 2004. Blended learning: Uncovering its transformative potential in higher education. The Internet and Higher Education, [e-journal] 7, pp.95-105. https://doi.org/10.1016/j.iheduc.2004.02.001.

Gerbic, P., 2011. Teaching using a blended approach - what does the literature tell us? Education Media International, 48(3), pp.221-234.

Graham, C.R., 2013. Emerging practice and research in blended learning. In: M. G. Moore, ed. Handbook of distance education. New York, NY: Routledge. pp. 333-350

Graham, C.R., 2006. Blended learning systems: Definition, current trends, and future directions. In: Curtis J. Bonk et Charles R. Graham. eds. 2006. The Handbook of Blended Learning. San Francisco, CA: Pfeiffer. pp. 3-21.

Guglielmino, L., 1977. Development of the Self-Directed Learning Readiness Scale. Ph. D. University of Georgia.

Horn, M.B. and Staker, H., 2015. Blended learning: Using disruptive innovation to improve schools. San Francisco, CA: Josey-Bass.

Ibrahim, M.M., Arshad, M.Y., Rosli, M.S. and Shukor, N.A., 2017. The Roles of Teacher and Students in Self-directed Learning Process Through Blended Problem-Based Learning. Sains Humanika, [e-journal] 9(1-4). https://doi.org/10.11113/sh.v9n1-4.1121.

Jézégou, A., 2014. Regard sur la Recherche « Dispositifs Hybrides dans l’Enseignement Supérieur » (Hy-Sup) : Avancées Majeures et Interprétation Possible de la Typologie Produite. Education \& Formation, [e-journal] e-301, pp.140-147.

Kane, L., 2004. Educators, learners and active learning methodologies. International Journal of Lifelong Education, [ejournal] 23, pp.275-286. https://doi.org/10.1080/0260/37042000229237. 
Kember, D., 1997. A reconceptualisation of the research into university academics' conceptions of teaching. Learning and instruction, 7(3), pp.255-275.

Kember, D. and Kwan, K., 2000. Lecturers' approaches to teaching and their relationship to conceptions of good teaching. Instructional Science. 28(5), pp. 469-490.

Kember, D., Leung, D.Y.P. and McNaught, C., 2008. A workshop activity to demonstrate that approaches to learning are influenced by the teaching and learning environment. Active Learning in Higher Education, [e-journal] 9(1), pp. 4356. https://doi.org/10.1177/1469787407086745.

Kintu, M.J., Zhu, C. and Kagambe, E., 2017. Blended learning effectiveness: the relationship between student characteristics, design features and outcomes. International Journal of Educational Technology in Higher Education, [e-journal] 14. https://doi.org/10.1186/s41239-017-0043-4.

Knowles, M. S., 1975. Self-directed learning: A Guide for Learners and Teachers. Cambridge, UK: The Adult Education Company.

Lam, J., 2014. The context of blended learning: The TIPS blended learning model, International Conference on Hybrid Learning and Continuing Education. Shanghai, China. Shanghai: Springer.

Lebrun, M., Peltier, C., Peraya, D., Burton, R. and Mancuso, G., 2014. Un nouveau regard sur la typologie des dispositifs hybrides de formation. Propositions méthodologiques pour identifier et comparer ces dispositifs. Éducation et formation, [e-journal] e-301, pp. 55-74. Available through: Genève University Library website < $\underline{\text { https://archive- }}$ ouverte.unige.ch/unige:37050> [Accessed 21 February 2020].

López-Pérez, M.V., Pérez-López, M.C. and Rodríguez-Ariza, L., 2011. Blended learning in higher education: Students' perceptions and their relation to outcomes. Computers \& Education, [e-journal] 56(3), pp. 818-826. https://doi.org/10.1016/j.compedu.2010.10.023.

Lounsbury, J.W., Levy, J.J., Park, S.-H., Gibson, L.W. and Smith, R., 2009. An investigation of the construct validity of the personality trait of self-directed learning. Learning and Individual Differences, [e-journal] 19(4), pp. 411-418. https://doi.org/10.1016/j.lindif.2009.03.001.

Loyens, S.M.M., Magda, J. and Rikers, R.M.J.P., 2008. Self-Directed Learning in Problem-Based Learning and its Relationships with Self-Regulated Learning. Educational Psychology Review, [e-journal] 20(4), pp.411-427. https://doi.org/10.1007/s10648-008-9082-7.

Noël, B. and Cartier, S.C. eds., 2016. De la métacognition à l'apprentissage autorégulé. Bruxelles: de Boeck Supérieur.

Page, J., Meehan-Andrews, T., Weerakkody, N., Hughes, D.L. and Rathner, J.A., 2017. Student perceptions and learning outcomes of blended learning in a massive first-year core physiology for allied health subjects. Advances in Physiology Education, [e-journal] 41, pp.44-55. https://doi.org/10.1152/advan.00005.2016.

Peraya, D. and Peltier, C., 2012. Dispositifs hybrides, nouvelle perspective pour une pédagogie renouvelée de l'enseignement supérieur. [pdf] Lyon: HY-SUP. Available at: http://prac-hysup.univ-lyon1.fr/spiralfiles/download?mode=inline\&data=1757974 $>$ [Accessed 21 February 2020].

Peraya, D., Charlier, B. and Deschryver, N., 2014. Une première approche de l'hybridation. Education et Formation, [ejournal] e-301, pp. 15-34. Available through: Genève University Library website < https://archiveouverte.unige.ch/unige:37049 > [Accessed 21 February 2020].

Peraya, D., Peltier, C., Villiot-Leclercq, E., Nagels, M., Morin, C., Burton, R. and Mancuso, G., 2012. Typologie des dispositifs de formations hybrides: configurations et métaphores. $27^{\text {th }}$ congress of AIPU. Quebec, Canada, May 2012.

Plush, S.E., and Kehrwald, B.A., 2014. Supporting New Academics' Use of Student-Centred Strategies in Traditional University Teaching. Journal of University Teaching \& Learning Practice, [e-journal] 11(1), pp.1-14. Available at: $<$ https://ro.uow.edu.au/cgi/viewcontent.cgi?article=1340\&context=jut|p> [Accessed 21 February 2020].

Poon, J., 2003. Blended Learning: An Institutional Approach for Enhancing Students' Learning Experiences. Journal of Online Learning and Teaching, [e-journal] 9(2), pp.271-289. Available at: <http://dro.deakin.edu.au/eserv/DU:30057995/poon-blendedlearning-2013.pdf> [Accessed 21 February 2020].

Prince, M., 2004. Does Active Learning Work? A Review of the Research. Journal of Engineering Education, [e-journal] 93, pp. 223-231. https://doi.org/10.1002/j.2168-9830.2004.tb00809.x.

Prosser, M., Martin, E., Trigwell, K., Ramsden, P. and Lueckenhausen, G., 2005. Academics' experiences of understanding of their subject matter and the relationship of this to their experiences of teaching and learning. Instructional Science, [e-journal] 33, pp. 137-157. https://doi.org/10.1007/s11251-004-7687-x.

Prosser, M. and Trigwell, K., 2006. Confirmatory factor analysis of the Approaches to Teaching Inventory. British Journal of Educational Psychology, [e-journal] 76, pp.405-419. https://doi.org/10.1348/000709905X43571.

Rimini, M. and Spiezia, V., 2016. Skills for a digital world, 2016 Ministerial meeting on the digital economy, OECD: OECD Digital Economy papers.

Saks, K. and Leijen, Ä., 2014. Distinguishing Self-directed and Self-regulated Learning and Measuring them in the E-learning Context. Procedia - Social and Behavioral Sciences, [e-journal] 112, pp. 190-198. https://doi.org/10.1016/j.sbspro.2014.01.1155.

Smit, K., de Brabander, C. J. and Martens, R. L., 2014. Student-centred and teacher-centred learning environment in prevocational secondary education: Psychological needs, and motivation. Scandinavian Journal of Educational Research, [e-journal] 58(6), pp. 695-712. https://doi.org/10.1080/00313831.2013.821090.

Sriarunrasme, J., Techataweewan, W., and Mebusaya, R.P., 2015. Blended learning Supporting Self-Directed Learning and Communication Skills of Srinakharinwirot University's first year students. Journal Social and Behavior Science. 197(2015), pp.1564-1569. https://doi.org/10.1016/j.sbspro.2015.07.111. 
Trautman, N.M., Carlsen, W.S., Eick, C.J., Gardner, F.E., Kenyon, L., Moscovici, H., Moore, J.C., Tompson, M., and West, S., 2003. Online Peer Review: Learning Sciences as It's Practices. Journal of College Science Teaching. 32(7), pp. $443-447$.

Trigwell, K. and Prosser, M., 2004. Development and use of the approaches to teaching inventory. Educational Psychology Review, 16, pp. 409-424. https://doi.org/10.1007/s10648-004-0007-9.

Trigwell, K., Prosser, M. and Ginns, P., 2005. Phenomenographic pedagogy and a revised Approaches to teaching inventory. Higher Education Research \& Development, [e-journal] 24, pp.349-360. https://doi.org/10.1080/07294360500284730.

Trigwell, K., Prosser, M., and Taylor, P., 1994. Qualitative differences in approaches to teaching first year university science. Higher Education, 27, pp. 75-84.

Trigwell, K., Prosser, M. and Waterhouse, F., 1999. Relations between teachers' approaches to teaching and students' approaches to learning. Higher Education, [e-journal] 37(1), pp. 57-70. https://doi.org/10.1023/A:1003548313194.

Uz, R. and Uzun, A., 2018. The Influence of Blended Learning Environment on Self-Regulated and Self-Directed Learning Skills of Learners. European Journal of Educational Research, [e-journal] 7, pp. 878-886. https://doi.org/10.12973/eu-jer.7.4.877.

Van den Akker, J., Bannan, B., Kelly, A.E., Nieveen, N. and Plomp, T., 2013. Curricular Development Research as a Specimen of Educational Design Research. In: Plomb, T. and Nieveen, N. 2013. Educational Design Research: An Introduction. Enschende: Slo.

Van Laer, S. and Elen, J., 2016. In search of attributes that support self-regulation in blended learning environments. Education and Information Technologies. https://doi.org/10.1007/s10639-016-9505-x.

Zimmerman, B.J., 2005. Attaining Self-Regulation: A Social Cognitive Perspective, in: Boekaerts, M., Pintrich, P.R. and Zeidner, M. eds. 2005, Handbook of Self-Regulation. California: Academic Press. pp. 13-35.

Zimmerman, B.J., 2002. Becoming a Self-Regulated Learner: An Overview. Theory into Practice, [e-journal] 41(2), pp.64-70. https://doi.org/10.1207/s15430421tip4102__2. 